\title{
The Curriculum and Education System of American Higher Tourism Education: Taking the School of Hotel Administration at Cornell University as an Example
}

\author{
ZHONG Lina ${ }^{1}$ \\ Beijing International Studies University, Tourism \\ Management School, Beijing, 100024, China
}

\author{
ZHOU Shaorui ${ }^{2}$ \\ Beijing International Studies University, Tourism \\ Management School, Beijing, 100024, China
}

\begin{abstract}
The curriculum setting is the core for higher tourism education. In this field, American has instructive experiences that are worthy of learning. In this paper, the researcher carries out an investigation to, on the one hand, analyze the university's advanced achievements in majors settings, course structure, and mode of instruction from the aspects of bachelor, master, doctor, and on the other hand to make a prospect of the future development of the curriculum for higher tourism education in China, by using the method of the literature analysis and interview with the College of Hotel Administration at Cornell University as an example case.
\end{abstract}

Keywords: the higher tourism education; tourism curriculum; Cornell University

\section{Introduction}

The school of Hotel Administration at Cornell University is a leading force in the development of tourism around the world. Thus, it is quite necessary for us to learn from the excellent results and experience of American higher tourism education and actively explore with creativity, to promote the development of higher tourism education in our country.

\section{Literature review}

The author finds that the main research methods are the case analysis and empirical analysis. Research field are mainly concentrated on curriculum and practical model.

About the curriculum setting, Liu Tingli (2003) compared the differences in the arrangement of courses in Cornell University and Beijing Union University. In the respect of the optimal design of tourism management curriculum system, Liu Aili (2012) came up with four rules based on the case analysis of Hotel Administration at Cornell University. Liu Chunying (2008) summarized that US system of higher education courses has the features of specialty, practicality and humanity based on the comparative analysis of Chinese and American curriculum system of higher education. Zheng Ying (2011) put forward nine revelations of American education on ours in terms of curriculum reform after the comparative analysis of the differences between Chinese and American education.

The practical model of American higher education, Huang Jianwei(2009) believed that Cooperative Education focuses on talent cultivation. On the "school-enterprise integration," the researchers Zhao (1998), based on the study of American education, thought that American higher education has always been for the demands of enterprise and tourism market. When studying the features of development of American tourism, Chen Xiaoyan (2010) found that higher tourism education in United States is mainly society demand-oriented which paid attention to the combination of theory and practice.

Throughout all the literature concerning the curriculum of higher tourism education both in China and America, as well as education systems, it can be found out that the researches focus on the horizontal comparative studies of the School of Hotel Administration at Cornell University and Chinese universities, while vertical ones on the structure and features of curriculum in School of Hotel Management at Cornell University are still in absence, therefore, the current study is carried out.

\section{Methods}

This paper firstly analyzes the typicality of choosing the School of Hotel Administration at Cornell University as a case study, and then, introduces the data and characteristics of major settings, course structures and teaching modes from the aspects of bachelor, master and doctor respectively, and raise prospects for the curriculum of higher education and system in our country.

This study is carried out via the data collation and analysis of secondary literature references and interview. First, get access to information in newspapers, magazines, papers, and the school's official website, collect, translate and analyze the collected data concerning the curriculum systems and teaching modes of the College of Hotel 
Management at Cornell University. On the basis of collected data, we interviews teachers and students who have learning experiences at Cornell University, asking them to add and correct the omissions of our secondary sources, and then, carries out the interviews to obtain firsthand information on the course.

\section{Typical analysis}

Tourism is a branch of the entire hospitality industry, together with the hotels, restaurants, transportation and other sectors. There are many similarities between the tourism management profession and the hospitality industry profession. Thus, we choose the School of Hotel Administration at Cornell University as the study object.

\subsection{Brief Introduction}

Cornell University was established in 1865 which is an American private Ivy League and federal land-grant research university. School of Hotel Administration at Cornell University was founded in 1922. It is the first American School of Hotel Administration, which is also recognized as the leading institutions among the other Hotel Administration School around the word. School of Hotel Administration at Cornell University accepts the undergraduate students from the US and 42 other countries, graduate students, and professionals from over 90 countries to receive the vocational manager training.

\subsection{Educational Philosophy}

The motto of Cornell university is: "I would found an institution where any person can find instruction in any study." The educational philosophy put by Cornell is that "instruction should be combined with education". That is, education must continuously adapt to the new demands of the industry. The goal of the School of Hotel Administration is "to cultivate the leader of hospitality industry in $21 \mathrm{st}$ century." In order to meet the different requirements of different students, Cornell university adapts the elective courses.

\section{Pattern of undergraduate education}

\subsection{Introduction}

Four years of schooling was designed for bachelor's degree program in the School of Hotel Management at Cornell University. All School of Hotel Administration students are required to work 800 hours in the hospitality industry to ensure the balance between the knowledge and practice. In addition, The curriculum is not only lay a solid foundation to develop the management functions but also offer many electives for students to develop their interests in a specific area of the hotel industry.

\subsection{The course structure}

\subsubsection{Curriculum system}

To graduate and get a bachelor's degree, students should get at least 120 credits. Students must complete the following seven kind of courses including required core courses, electives, concentration electives, free electives, foreign languages, gym classes, and practice credit. Table 1 illustrates the] information about core curriculum of undergraduate education.

\begin{tabular}{cl}
\hline $\begin{array}{c}\text { System } \\
\text { Structure }\end{array}$ & \multicolumn{1}{c}{ Curriculum Classification } \\
\hline & Planning and Design \\
& Finance and accounting \\
& Information System \\
& Law \\
Core & Managerial and Organizational \\
Curses & Human-Resource \\
& Management \\
& Managerial Communication \\
& Marketing and Strategy \\
& Operations \\
\hline Table 1 Curriculum of undergraduates
\end{tabular}

\subsubsection{Course requirements}

Hotel management school of Cornell University requires that undergraduate should complete the following requirements: A)Complete study lasted for eight semesters in the school and complete at least 12 class hours after admission. B) Obtain At least 120 credits, not including credits of physical education. C) As for the prescribed courses, the accumulation of average grade point is 2 . D) Students must live in the school in the last semester. Students can apply for living out of school if they reach all the requirements of graduation and the accumulation of grade point average is 3 .

\subsection{The characteristics of the course}

The school of Hotel management at Cornell University sets up 150 courses relating to 9 professional fields for undergraduate education. In the frame of the course, except for 22 imperative courses with 65 credits of core curriculum, the remaining courses can be completed by students to choose.The combination of compulsory and elective teaching is helpful to inspire students' interest in majors and also ensures the quality of teaching.

\subsubsection{The teaching hotel}

The School of Hotel Administration aimed to create a first-class academic institution which focused on the operation of hotels and restaurants. Many hotel giants invested and set multiple funds for teaching. Thus, the School of Hotel Administration owned the most comprehensive library of hotel management and a training hotel with 150 rooms. This guarantee the college can develop steadily no matter under what circumstances. It 
also provides students with the practice base in the campus, sending the top talents to hospitality industry continuously.

\subsubsection{The Center for Hospitality $\operatorname{Research}(\mathrm{CHR})$}

The Center for Hospitality Research, established in 1992 , is the main platform for the cooperation of industry study research. It creates new knowledge-and shares that knowledge to power hospitality forward. At round tables and other meetings, Cornell University's School of Hotel Administration faculty, corporate partners, and other industry leaders collaborate to frame timely issues and understand important topics.

The research achievements of CHR has a variety of publications: journals, Cornell hotel management quarterly, CHR reports, round-table forum, etc. These insights are captured in research reports and industry tools that are available online at no cost. In addition, the research are willing to incorporate these vivid cases into their teaching which combine the theory with practice.

\subsubsection{Seminars of industry leaders}

The curriculum of the School of Hotel Management is flexible and diverse. Group discussions, case analysis, and series of lecture are offered for students. Cornell University held the annual seminars of industry leaders. The president of industry executives invite the industry leaders to do the lectures about interpersonal relationship in the work environment, occupation development trend, and occupation moral from an all-round multi-angle presentation.

Hundreds of heavyweights will come to the School of Hotel Administration at Cornell to have a speech. After the lecture, senior students can discuss with the guests, a few people will have the opportunity to have dinner with the guests, which not only encourage students to strengthen their understanding of the present situation and prospects of the industry, but also pay attention to the cultivation of students' professional qualities.

\subsubsection{Restoring Real Cases}

The main teaching methods of School of Hotel Administration are based on cases-analysis by using multimedia, class discussion, simulations and other means to implement teaching activities. For instance, when the full-time teachers explain the course of timeshare theory, the scope of their work is limited to management, registration and other routine matters.

Middle level management staff in Marriott Hotel has responsibility for the specific knowledge, the development, financing, marketing and legal of timeshare theory are taught by engineering, finance and marketing department. All the data and materials are originated from the real cases of Marriott Hotel, which gives students chances to experience the whole process of hotel's timeshare theory from its planning, development, sale, and management, at the end of courses, industry leaders will give lectures on the theory's trend development.

\section{Pattern of master and doctoral education}

\subsection{Introduction}

The MMH was designed to cultivate the industry leader with outstanding innovation no matter which direction you start the hotel industry. In this paper, the researcher choose $\mathrm{MMH}, \mathrm{MS}$ and PhD to carry out the research.

\subsection{The Master of Management in Hospitality (MMH)}

The Master of Management in Hospitality (MMH) is an intensive three-semester hospitality-focused graduate business management AACSB-accredited degree, the only one of its kind at an Ivy League institution. The project starts from May every year, for 12 months, the students have great opportunities to meet the outstanding alumni around the world.

Just as the Master of Business Administration (MBI), the MMH prepares students to be theory-based, action-oriented leaders of executive management teams and entrepreneurial ventures. MMH graduates are entrepreneurs, restaurateurs, developers, analysts, consultants, corporate directors, and managers of hotels, resorts, and spas.

\subsection{Programs for MS and PhD}

$\mathrm{MS}$ and $\mathrm{PhD}$ are special projects only open for the students who plan to teach or conduct researches in the college. Master stage lasts for four semesters, and $\mathrm{PhD}$ for eight semesters. Once being admitted to any project, students will enter a special committee of the School of graduate members (two MS candidates and three $\mathrm{PhD}$ candidates), members will guide these candidates to learn well according to their backgrounds and interests in the curriculum.

Each degree candidates will have a wide knowledge of hotel management, learn the study methods and statistical methods, and get the teaching and management skills to become more proficient in the field of in-depth study .

\subsection{Curriculum structure}

\subsubsection{Curriculum structure of MMH}

In the system of master curriculum, the total credits are 48 , of which 29 credits are for core courses, 15 credits are for concentration courses and 4 credits are for free electives. The senior managers will make special instruction program for students, and in the first year, students have two weeks internship with the guidance of manager.

\subsubsection{Curriculum structure of $\mathrm{MS}$ and $\mathrm{PhD}$}

All MS students must complete a minimum of 16 total classes and get at least 12 points in each semester all 48 points should be obtained finally. The courses has been decided by the special committee including the appropriate method, theory and application. All PhD students must 
complete a minimum of 16 total classes; four classes per semester for two years, five of which must be researchbased.

With regard to practice in master's and doctoral stages, along with operation skills, these aspects including capacity of management, working experience, the background of internationalization, analysis ability and the capacity of transforming theoretical knowledge into practical management experience will also be given more attention. For instance, in terms of some specific problems of hotel operation, there is a need of field research and project analysis to get solutions, and these solutions will be displayed to senior administrators and enterprisers in order to improve their abilities of decision making and management.

\section{Enlightenment}

Through the curriculum setting and its practical feature ranging from bachelor, master and doctor degree at Hotel Management School of Cornell University, we can conclude that the curriculum should be closely integrated with the market demand, as well as take the personality development of students into account.

\subsection{Build up a personalized curriculum system}

Along with China's opening up, a variety of new formats are in rapid development, thus, international management talents who have foreign language expertise are in great demand, and requirements for tourism practitioners are in constant elevation. This requires colleges to have a clear orientation of the training program, know more about market dynamics and adjust the curriculum in terms of market changes, curriculum frameworks, credit hour allocated, textbook selection and teaching methods. Besides, they need to adapt to the complex and volatile market environment to meet the needs of students about personalized curriculum demand and then put forward a program that can interest students and be accepted by the society.

\subsection{Strengthen the school-enterprise cooperation}

Tourism subject emerged from the development of market. This requires colleges to pay close attention to market dynamics, and increase course hours of practical lessons so as to maintain a balance between theory and practice. Universities can work with related companies, and hire business elites as visiting professors using case teaching, field research, scenario simulation and other teaching techniques to carry out teaching activities to accumulate practical experience, better knowledge system, and endow students with ability to deal with core business, as well as with leadership and professional skills that a new generation of manager should have.

For the specific curriculum design, it should combine campus and off-campus internship training to build a platform for students to come to practice and learn from the practice, thus they will be aware of their deficiencies in practice and take the initiative to make up for the shortcomings and enhance their overall quality.

\subsection{Establish partnerships with well-known foreign universities}

Through the complex, ever-changing international environment, colleges should learn from other institutions about personnel training and training ideas and thus establish academic research, student exchanging, internship partnership practices for the assistance to development of talents with international profession.

\section{CONCLUSIONS}

In the curriculum setting, we have to realize the changing, diversified, personalized curriculum system and teaching methods, as well as the high-quality practical training system that is the core of the curriculum design. Curriculum design should meet the law of learning for students', and internship, practice courses echo the goal of professional development.

\section{References}

[1] Chen. X, The Characteristics of Higher Education of Tourism in Japan, America, and Switzerland. Journal of Hubei University of Education, pp.120-122, 2010.

[2] Hu. X, The Preliminary Exploration of Optimal Design of Master Curriculum of Tourism Management in our Country--Based on the Revelation of the Tourism Course Features at Universities in Murry. Sichuan Normal University, 2012.

[3] Huang. J, Comparative Study of Tourism College Industry-university-Research Model on the School of Hotel Administration of Cornell and Beijing Union University. Tourism Tribune. pp. 87-91, 2009.

[4] Liu. A \& Zhang. Y\& Yao. C, the Discussion of Tourism management curriculum system design--- on Cornell School of Hotel Administration. Capital Normal University, pp. 42-46, 2012.

[5] Liu. C, The Comparative Study of the Curriculum System of Higher Education of Tourism Between America and China. Liaoning Normal University, 2008.

[6] Liu. T, The True Case Analysis of Hotel Administration Major in Domestic and Foreign Hotels --- Taking the School of Hotel Administration at Cornell University and the College of Tourism at Beijing Union University as an Example. Tourism Tribune. pp. 73-74, 2004.

[7] Zhao. P, Studies on the American Tourism College Education Model of "University- Industry", Guilin Tourism College, pp. 68-70, 1998.

[8] Zhen. Y, The Comparative Study of Undergraduate Education Between America and China. Liaoning Normal University, 2011. 